Fifteen special articles are included in this bulletin, as well as brief abstracts of recent publications on grassland in Australia.

\section{Power Development in Turkey}

Energetic steps are now being taken by the Government to open up the market in the southeast corner of Europe to British industry. According to the Electrical Times of May 2, one of the first results of this active trade policy was shown by the recent announcement of the signing of a contract between the Turkish Government institution known as the Eti-Bank and the Metropolitan-Vickers Electrical Co., Ltd., which has a value of approximately one and a half million pounds. A few details of the contract are available. It covers the electrification of a large and important area, including the construction of a power station at Catalagzi on the Anatolian coast of the Black Sea. One of the main objects of the scheme is the provision of electric power for the modernization and expansion of the Turkish coal industry, and the site of the power station has been chosen for its proximity to the Zonguldak coal basin, from which the station fuel will be derived. The present contract includes the building and equipment of a $60,000 \mathrm{kw}$. steam power station, and the provision of switchgear, overhead lines and three substations for a transmission system about $16 \mathrm{~km}$. in length. Provision is to be made for the extension of the scheme at some future date.

The initial generating plant will consist of three $20,000 \mathrm{kw}$. turbo-alternator sets, to operate at 3,000 r.p.m., with Metrovick central flow condensers and four-stage feed-heating, incorporating lowpressure evaporators for make-up supply. Sea-water will be used for cooling and will be supplied from a separate pump-house to be constructed on the shore. The main alternators will generate at 11,000 volts; and each set will include a 1,500 kw. house-service alternator. A $375 \mathrm{kw}$. Diesel engine set will also be provided for stand-by service to the station auxiliaries. Transmission to the substation will be at 66,000 volts, the station output being stepped up to this voltage in an outdoor transformer and switching station adjoining the power station and controlled from an indoor controlled board. The main transformers will be 25,000 kva., 11/16 kv., 3-phase units. The equipments of the substations will include nine 6,400 kva., $66 / 15 \mathrm{kv}$. outdoor transformers and $15 \mathrm{kv}$. indoor switchgear.

\section{Alluvial Gold Dredging in the Gold Coast Colony}

AN interesting account is given in the G.E.C. Journal of February of the electrical equipment for the Bremang Gold Dredging Co., Ltd. This company dredges for alluvial gold on the Ankobra River, one of the larger rivers of the Gold Coast Colony, which flows roughly north and south and pours itself into the Gulf of Guinea. Many of the shallows of the river are sufficiently rich in alluvial gold deposits to warrant commercial development, and the Bremang Gold Dredging Co., Ltd., has installed equipment at two of these points for dredging mud and gravel from the river bed from which the gold is recovered. The dredges are electrically operated and are supplied from individual substations fed by a $55 \mathrm{kv}$. overhead transmission line from the power station of Ankobra Junction, a distance of about twenty miles.

The power station and the various camps from which the dredging operations are conducted are situated some $6^{\circ}$ north of the equator in what was originally bush country with a humid tropical climate, but very great improvements in living conditions have been made in recent years. The bungalows provided for the accommodation of the European staff are of the most up-to-date type, with modern sanitary arrangements, electric light, fans, and running water supplied from specially constructed tanks. As regards diet, most of the vegetables are canned, but fresh potatoes are obtainable from Madeira, and green vegetables, such as lettuce and cabbage, can be grown locally provided the soil is adequately watered and sheltered from the sun. Cheese and butter are also available, and can now be kept in good condition almost indefinitely as a result of the installation of domestic refrigerators in the bungalows. Wireless programmes are provided by a local company at Prestea, and a relay station has been instituted in each camp with loud speakers in the individual bungalows. The native labour employed is recruited from local villages.

\section{New Type of Rubber Paving Block}

IN Roads and Road Construction of May 1 it is stated that Marylebone Borough Highways Committee reports that Universal Rubber Paviours, Ltd., of Manchester, have offered to provide and lay, free of cost to the Council, approximately 300 square yards of a new type of rubber paving block. The Council has already approved of the renewal of the concrete foundation and wood paving in Duke Street (Wigmore Street to Edward's Mews) which is considered to be a suitable site for the rubber paving. Other alternatives have been considered, but as the paving is to be subjected to skidding and other tests by the Ministry of Transport, it is necessary for the whole width of the carriageway to be paved with rubber and the section of Duke Street in question is of the desired width and length for the tests. The acting borough engineer reports that the new type of block appears to be an improvement on those laid by the same Company in Allsop Place, by Clarence Gate, some six years ago. By accepting the offer, the Council will save approximately $£ 400$ on the provision of wood blocks for the section of the carriageway in question.

\section{National Radium 'Trust and Radium Commission}

The tenth annual reports of the National Radium Trust and Radium Commission (1938-1939) follow the general form of previous reports, but constitute, owing to special difficulties in planning for future developments, a more tenuous publication than usual. One of the most important events external to the chief work of the Commission has been the passing of the Cancer Act on March 29, 1939 ; this naturally receives 